\author{
Jurnal Ekonomi Modernisasi \\ http://ejournal.unikama.ac.id/index.php/JEKO \\ JEM 13 (2) 2017, 105-118
}

\title{
Pembelajaran Organisasi UKM untuk Menciptakan Keunggulan Bersaing
}

\author{
Fathor A.S ${ }^{1}$, Mohammad Arief ${ }^{2}$ \\ Fakultas Ekonomi dan Bisnis, Universitas Trunojoyo Madura
}

\begin{abstract}
The purpose of article writing is to develop a conceptual framework of organizational learning for SMEs to create competitive advantage. Individual knowledge in organizations is the key to success in organizational learning. The application of organizational learning can be used to develop the organization through the determination of organizational design. Organizations in the learning stages should be directed to the organic organizational design as it encourages individuals to demonstrate innovative behavior, increased efficiency, effective and appropriate change applied to uncertain environments. This can create competitive advantage for SMEs.
\end{abstract}

Keywords: Organization; SMEs; Competitiveness; Knowledge; Learning

Abstrak

Tujuan penulisan artikel untuk menyusun kerangka konseptual pembelajaran organisasi bagi UKM dalam rangka menciptakan keunggulan bersaing. Pengetahuan individu dalam organisasi merupakan kunci sukses dalam pembelajaran organisasi. Penerapan pembelajaran organisasi dapat digunakan untuk mengembangkan organisasi melalui penentuan desain organisasi. Organisasi dalam tahap pembelajaran sebaiknya diarahkan pada desain organisasi organik karena mendorong individu untuk menunjukkan perilaku inovatif, peningkatan efisiensi, perubahan yang efektif serta sesuai diterapkan pada lingkungan yang tidak pasti. Hal ini dapat menciptakan keunggulan bersaing bagi UKM.

Kata kunci: Organisasi; UKM; Daya Saing; Pengetahuan; Pembelajaran

\footnotetext{
Permalink/DOI : http://dx.doi.org/10.21067/jem.v13i2.1922

Cara mengutip : A.S, F., \& Arief, M. (2017). Pembelajaran Organisasi UMKM untuk Menciptakan Keunggulan Bersaing. Jurnal Ekonomi Modernisasi, 13(2), 105118. doi:http://dx.doi.org/10.21067/jem.v13i2.1922

Sejarah Artikel : Artikel diterima : Mei 2016; direvisi Juni 2017; disetujui Juli 2017
}

\footnotetext{
Alamat korespondensi :

Fakultas Ekonomi dan Bisnis, Universitas Trunojo Madura

Jl. Raya Telang, Kamal, Madura, Indonesia 69162

E-mail: papi.arief@gmail.com
}

ISSN 0216-373X (cetak) 


\section{Pendahuluan}

Indikasi kelemahan UKM dalam meningkatkan daya saing adalah UKM kurang melakukan pembelajaran. Baker dan Sinkula, (1999), menjelaskan bahwa kekurangan pengetahuan dan SDM yang berkualitas menjadi faktor penting bagi UKM untuk meningkatkan daya saing. Secara eksplisit, kelemahan yang dimiliki oleh UKM menunjukkan kelemahan mereka dalam melakukan pembelajaran, khususnya dalam melakukan pembelajaran yang berkaitan dengan pengetahuan. Pada kondisi ini proses pembelajaran UKM merupakan salah satu komponen yang penting dan menjadi faktor kritis dalam menjalankan aktivitas bisnis.

Selama ini, sistem transformasi yang terjadi pada organisasi termasuk UKM menggambarkan suatu proses pembelajaran, perubahan perilaku dan pengembangan kinerja (Slater dan Narver, 1995). Pembelajaran organisasi merupakan fenomena sosial. Setiap pembelajaran yang dilakukan oleh individu tergantung dari pengetahuan yang dimiliki oleh anggota suatu organisasi (Figueiredo, 2003). Currado (2006) menyatakan bahwa interaksi sosial yang terjadi tidak hanya memfasilitasi komunikasi dan koordinasi, tetapi juga makna pembelajaran yang dilakukan. Implikasi dari penjelasan tersebut mengindikasikan bahwa ketika organisasi melakukan proses pembelajaran maka faktor pengetahuan merupakan komponen yang akan digunakan untuk mengeksplorasi dan mengeksploitasi pembelajaran tersebut.

Dalam pembelajaran organisasi, eksplorasi pembelajaran secara rutin yang dilakukan oleh organisasi mempermudah pengembangan produk dan proses baru (March, 1991; Peng Yu, 2017). Fleksibilitas, penelitian, pengambilan risiko, eksperimen dan inovasi merupakan komponen penting pengetahuan. Adapun eksploitasi pembelajaran yang dilakukan oleh organisasi secara rutin untuk memperbaiki produk, proses dan pengetahuan. Pilihan strategi, produksi, efisiensi, seleksi, implementasi dan eksekusi merupakan komponen penting dari pengetahuan.

Menurut sudut pandang strategi, salah satu faktor kritis yang dapat dilakukan oleh UKM untuk mencapai keunggulan bersaing adalah melalui individu (Pfeffer, 1994). Pengetahuan yang dimiliki oleh individu akan mendorong timbulnya pengalaman. Pengetahuan dan pengalaman yang dimiliki oleh individu pada akhirnya akan menjadi proses pembelajaran, baik bagi individu dan UKM. Dengan pembelajaran, maka sikap dan perilaku akan dapat ditingkatkan.

Huizing dan Bouman (2002) menjelaskan bahwa konsepsi strategis organisasi selalu melibatkan pembelajaran organisasi yang dihasilkan dari pengetahuan individu dalam organisasi, sehingga pengetahuan merupakan disiplin organisasi yang menghubungkan antara informasi tentang permintaan dan penawaran yang selanjutnya dapat mendukung organisasi untuk menciptakan pembelajaran. Hubungan empiris ini dikembangkan dalam berbagai literatur seperti Crossan, et al, (1999); Bontis, et al, (2002); Crossan dan Hulland, (2002); Crossan dan Berdrow, (2003), Wei, et al, (2013) yang menyatakan bahwa terdapat hubungan antara strategi dan pembelajaran organisasi yang diciptakan melalui pengetahuan. Antal, et al. (2003) mendukung be- 


\section{Fathor A.S \& Mohammad Arief / Pembelajaran Organisasi UKM....}

berapa pernyataan tersebut dengan mengemukakan bahwa terdapat dua domain dalam pembelajaran organisasi, pertama, mengingat pengetahuan yang sudah ada sebelumnya dan kedua menganalisis bagaimana menciptakan pengetahuan yang baru.

Organisasi yang mengembangkan kapasitas untuk beradaptasi dan berubah secara kontinyu dikenal sebagai pembelajaran organisasi. Pembelajaran organisasi merupakan hal yang sangat penting untuk menciptakan keunggulan bersaing (Baker dan Sinkula,1999; Hult, 1998; Hult dan Ferrell, 1997a; Hurley dan Hult, 1998; Lukas, et al., 1996; Sinkula, 1994; Sinkula, et al., 1997; Slater dan Narver, 1994, 1995). Dalam proses pembelajaran organisasi, beberapa orang akan berdampingan dengan pola pemikirannya dan secara bebas berbagi ide dengan orang lain, membentuk visi organisasi, serta bekerja bersama-sama merencanakan pencapaian visi tersebut. Secara khusus, proses pembelajaran dapat dilakukan melalui langkah-langkah sebagai berikut: (1) Membangun komitmen terhadap perubahan, (2) Mengadopsi struktur organisasi informal, dan

Mengembangkan budaya organisasi terbuka.

Pembelajaran organisasi merupakan fungsi dari dua konsep yang berbeda, meliputi, (1) proses pembelajaran organisasi dan (2) struktur pembelajaran organisasi. Berdasarkan prosesnya, pembelajaran organisasi sebagaimana yang dijelaskan oleh Slater dan Narver (1995) sebagai bentuk pengembangan dari pengetahuan organisasi yang dipengaruhi oleh perilaku individu. Sedangkan pembelajaran organisasi yang didasarkan pada strukturnya, dijelaskan oleh Garvin (1993) sebagai proses pemindahan pengetahuan, ketrampilan dan modifikasi perilaku dari pengetahuan yang dimiliki oleh individu sebelumnya. Selanjutnya, Slater dan Narver (1994) menjelaskan bahwa organisasi yang melakukan pembelajaran akan menghilangkan pengetahuan yang dimiliki sebelumnya untuk kemudian digantikan dengan pengetahuan yang baru dan diterapkan pada aktivitas yang akan dilakukan. Ketika organisasi mentransfer pengetahuan yang baru ke dalam aktivitas yang akan dikerjakan, maka mereka telah melakukan inovasi yang dapat menciptakan keunggulan bersaing.

Damanpour (1992) menyatakan inovasi sebagai adopsi dari ide-ide atau perilaku, dalam system, kebijakan, program, proses, barang dan jasa, sebagai hal baru dalam organisasi. Sedangkan Porter dan Stern (1999) menyatakan pengertian merupakan transformasi dari pengetahuan pada produk baru, proses dan layanan dengan melibatkan lebih banyak ilmu pengetahuan dan teknologi. Cornwall dan Perlman (1990) mengatakan bahwa organisasi dapat melakukan inovasi secara internal melalui strategi yang disusun, struktur dan proses. Drucker (1985) menjelaskan bahwa penyediaan inovasi secara terstruktur dapat digambarkan dan dimonitor melalui 7 sumber peluang, yaitu (1) yang tidak diharapkan, (2) incangruities, (3) kebutuhan akan proses, (4) struktur pasar dan industri, (5) demografi, (6) perubahan persepsi, dan (7) pengetahuan baru. Hal ini karena inovasi dan kewirausahaan pada organisasi membutuhkan ruang bagi aktivitas manajerial dan kapasitas wirausaha serta skills untuk 


\section{Jurnal Ekonomi Modernisasi, 13 (2) 2017, 105-118}

menangkap peluang yang ada melalui inovasi. Berdasarkan latar belakang teori maka penulisan artikel ini bertujuan untuk menyusun kerangka konseptual pembelajaran organisasi bagi UKM dalam meningkatkan daya saing.

\section{Pembahasan}

\section{Upaya Menemukan Pembelajaran da- lam Organisasi}

Upaya untuk meningkatkan sumberdaya yang didasarkan pada pengetahuan, perusahaan harus selalu mempromosikan pembelajaran organisasi (Tetrick dan Da Silva,2003; Ghili, et al., 2013). Pengetahuan akan mampu menciptakan efisiensi pada organisasi (Hitt, et al, 2001a.) dan menciptakan kompetensi (Collis, 1991; Winter, 1987). Pengetahuan akan menghindarkan organisasi untuk ditiru oleh pesaing sehingga masing-masing mempunyai keunikan yang berbeda untuk menciptakan keunggulan bersaing (Lei, et al, 1996). Sedangkan kompetensi akan menyebabkan organisasi dapat membangun dan mengintegrasikan kemampuan internal dan eksternal didalam menghadapi perubahan lingkungan yang cepat (Teece, et al, 1997). Levitt dan March, (1988); Szulanski, (2003) menjelaskan bahwa kompetensi yang dimiliki oleh organisasi muncul sebagai proses pembelajaran.

Pembelajaran organisasi dapat dilakukan dengan melakukan program pelatihan dan pengembangan lainnya. Program ini bertujuan untuk meningkatkan modal pengetahuan organisasi. Beberapa organisasi menganggap bahwa mereka mempunyai sumberdaya manusia dengan penge- tahuan dan kompetensi yang paling baik dan dapat digunakan sebagai faktor pembeda dengan organisasi yang lain (DeNisi, et al, 2003). Secara definitif, beberapa penulis memberikan artikulasi yang berbeda mengenai pelatihan dan pengembangan. Pelatihan (training) dimaksudkan untuk memperbaiki penguasaan berbagai keterampilan dan teknik pelaksanaan kerja tertentu, terinci dan rutin. Pengembangan dimaksudkan untuk memperbaiki dan meningkatkan pengetahuan, kemampuan, sikap dan kepribadian.

Keberhasilan orientasi ataupun jenis pelatihan lainnya dapat dilihat dari jumlah proses belajar yang muncul dan ditransfer ke dalam pekerjaan. Jika organisasi sering melakukan pelatihan yang tidak direncanakan, tidak terkoordinasi, dan tidak serius maka akan mengurangi proses belajar secara signifikan. Pelatihan dan proses belajar akan terjadi, yaitu melalui kelompok kerja yang bersifat informal, baik organisasi itu mempunyai usaha yang terkoordinasi atau tidak, karena karyawan belajar dari satu sama lain. akan tetapi, tanpa pelatihan yang dirancang dengan baik dan dengan pendekatan yang sistematis, apa yang dipelajari kemungkinan bukan sesuatu yang terbaik bagi organisasi.

Pembelajaran organisasi merupakan salah satu bentuk pengembangan organisasi yang didasarkan pada pengetahuan. Secara empiris, Cook dan Yanow (1995) menyatakan bahwa organisasi dapat melakukan pembelajaran. Hal ini karena dalam organisasi terdapat sekelompok individu sehingga pembelajaran organisasi diarahkan pada pengetahuan yang dimiliki oleh individu. Pengetahuan individu yang menghasilkan 


\section{Fathor A.S \& Mohammad Arief / Pembelajaran Organisasi UKM....}

pembelajaran merupakan proses pembelajaran organisasi. Proses peniruan yang dilakukan oleh organisasi terhadap pesaing juga termasuk ke dalam pembelajaran namun organisasi yang melakukan pembelajaran dengan cara seperti ini sulit untuk mendapatkan keunggulan bersaing dalam jangka waktu yang lama (DeNisi, et al, 2003).

Pembelajaran organisasi juga dapat ditemukan pada tingkatan yang dimiliki oleh organisasi. Garvin (1993) berpendapat bahwa pengembangan terhadap pembelajaran organisasi terdiri dari 3 tingkatan. Tahap pertama, meningkatkan kemampuan kognitif individu yang ada pada organisasi. Pada tahap ini, individu dalam organisasi harus mengeluarkan ide-ide baru yang akan mengakibatkan mereka mengembangkan pengetahuan dan mulai berpikir dengan cara yang berbeda. Tahap kedua, meningkatkan perilaku dari individu. Individu dalam organisasi menginterpretasikan perspektif baru yang dapat menimbulkan konsekuensi pada perubahan perilakunya. Tahap ketiga, peningkatan kinerja. Tahapan ini dapat dilakukan ketika individu mengalami perubahan perilaku yang mengarah pada perbaikan kualitas.

Pembelajaran organisasi adalah keterlibatan setiap orang dalam proses pengidentifikasian dan penyelesaian masalah, sehingga memungkinkan organisasi untuk melakukan eksperimen, melakukan perbaikan dan meningkatkan kemampuannya terus menerus. Daft (2006) mengemukakan bahwa terdapat beberapa karakteristik dari pembelajaran organisasi yaitu: (1) Struktur berbasis tim, (2) Pemberdayaan karyawan, dan (3) Informasi terbuka.
Pada paradigma tradisional, pembelajaran dianggap sebagai sebuah proses yang terpusat pada penyimpanan informasi dalam memori. Dalam perkembangannya, Antal, et al. (2003) mengemukakan bahwa pembelajaran merupakan cara yang dilakukan oleh organisasi untuk fokus pada proses membentuk dan menghasilkan pengetahuan. Pendapat ini memperkuat pernyataan Miller (1996) yang menjelaskan pembelajaran organisasi sebagai akuisisi pengetahuan yang dilakukan oleh individu atau kelompok dan diterapkan pada proses pengambilan keputusan atau untuk mempengaruhi individu lain yang ada pada organisasi. Penjelasan tersebut mengindikasikan bahwa pembelajaran dapat diciptakan melalui pengetahuan yang dimiliki oleh para pelaku, meliputi individu atau kelompok.

Berdasarkan hasil kajian empiris yang dilakukan oleh Sinkula (1994); Slater dan Narver (1994, 1995), pembelajaran organisasi merupakan suatu fungsi yang terdiri dari 3 tahapan proses, yaitu: (1) Akuisisi informasi (information acquisition), menunjukkan suatu kumpulan dan penentuan dari kebutuhan atau preferensi pelanggan (seperti pembelian internal) dan tantangan dari organisasi, (seperti langkah yang akan diambil, serta lingkungan makro) yang dapat berpengaruh dalam pengembangan organisasi dan memperjelas dari kebutuhan tersebut, (2) Diseminasi informasi (information dissemination), proses untuk menjelaskan informasi yang diterima dan pertukaran informasi yang dapat memberikan manfaat bagi organisasi (Kohli, et al., 1993), (3) Pembagian interpretasi (shared interpretation), proses yang dilalui 
untuk mencari makna dari informasi yang diterima (Daft dan Weick, 1987).

Pawlowsky (2003) menjelaskan bahwa tahapan yang ada pada proses pembelajaran organisasi dilalui dalam empat tahap, yaitu: (1) Identifikasi informasi yang relevan untuk pembelajaran, untuk penciptaan pengetahuan baru, atau keduanya, (2) Pertukaran dan difusi pengetahuan, baik dari individu untuk tingkat kolektif atau pada tingkat kolektif kedirinya sendiri, (3) Integrasi pengetahuan kedalam sistem pengetahuan yang ada pada tingkat kolektif, tingkat individu, atau keduanya, atau kedalam aturan prosedural organisasi, dimana baik integrasi maupun modifikasi dari sistem yang diadopsi bisa terjadi, dan (4) Transformasi dari pengetahuan baru menjadi tindakan dan pengaplikasian ulang dari pengetahuan dalam rutinitas organisasi, sehingga mempengaruhi perilaku organisasi.

Pembelajaran organisasi merupakan proses dinamis yang tidak hanya terjadi melalui waktu, tetapi juga melalui tingkat atau dimensi yang berbeda dari organisasi. Dinamisasi dalam proses pembelajaran organisasi terjadi dari gab atau pertentangan yang ada pada pengetahuan baru yang dimiliki oleh individu (feed forward) dan pengetahuan yang sudah ada pada organisasi (feed back). Pertentangan ini terjadi karena pembelajaran organisasi tidak hanya dikaitkan dengan proses inovasi yang akan menghasilkan sesuatu yang baru, tetapi juga berkaitan dengan proses umpan balik dalam bentuk menemukan cara untuk mengeksplorasi apa yang telah dimiliki (Crossan, et al, 1999).

Berdasarkan beberapa pendapat mengenai feed forward dan feed back, dapat disimpulkan bahwa pembelajaran organ- isasi harus terjadi pada pembelajaran yang sebenarnya. Garvin (1993) menyatakan bahwa pembelajaran organisasi merupakan salah satu dari proses pembuatan, perolehan dan transfer pengetahuan yang dapat merubah perilaku yang mencerminkan pengetahuan dan perspektif baru.

Secara tradisional, antara teori dan praktek terdapat kesamaan pembelajaran yang dilakukan oleh organisasi. Hult, Ferrell dan Hurley (2002) melakukan sintesa dari model pembelajaran organisasi yang didasarkan pada kajian empiris sebelumnya. Secara detail, model yang dikembangkan pada pembelajaran organisasi terdiri dari 4 orientasi, yaitu: (1) Orientasi pada kelompok, tingkatan dimana organisasi melakukan kerjasama untuk mengambil suatu keputusan, (2) Orientasi pada system, tingkatan dimana organisasi menekankan pada sistem yang ada digunakan sebagai dasar untuk melakukan aktivitas, (3) Orientasi pada pembelajaran, tingkatan organisasi yang menekankan pada nilai suatu pembelajaran yang dilakukan untuk mencapai keuntungan jangka panjang, dan (4) Orientasi pada memori, tingkatan dimana organisasi menekankan pada komunikasi untuk meningkatkan pengetahuan. Masing-masing orientasi tersebut mampu menjelaskan komponen yang dapat digunakan pada proses pembelajaran organisasi. Meskipun demikian, orientasi tersebut dapat dicapai pada organisasi yang menerapkan struktur organik (Sinkula, et al, 1997) dan bukan struktur mekanis. Hal ini cukup beralasan mengingat desain organik mempunyai karakteristik low formalization dan low centralization dapat mendorong individu yang ada pada organisasi untuk menunjukkan perilaku yang inovatif. 


\section{Fathor A.S \& Mohammad Arief / Pembelajaran Organisasi UKM....}

\section{Pengetahuan Sumber Keunggulan Ber- saing}

Dalam perspektif sumberdaya, pengetahuan merupakan komponen yang dapat menciptakan keunggulan bersaing bagi organisasi (Thornhill, 2006). Pengetahuan sebagai suatu aset dapat digunakan sebagai alat untuk menunjukkan nilai, jarang untuk diperhatikan oleh organisasi yang lain dan sulit untuk ditiru oleh pesaing. Pengetahuan dapat dikaitkan dengan kinerja organisasi (Barney, 1991). Selanjutnya, Kogut dan Zander, (1996); Spender (1996) menyatakan bahwa pengetahuan dijelaskan sebagai sumberdaya kritis dari organisasi yang dikaitkan dengan bagian yang lain. Batasan yang ada pada pengetahuan akan membuat organisasi mampu untuk mengambil tindakan dan membedakan diri dengan pesaing (King dan Zeithalm, 2003; Leonard-Barton,1992).

Secara definitif, pengetahuan dapat dijelaskan sebagai bentuk informasi yang mempunyai nilai tinggi (baik secara eksplisit maupun tacit) yang mengkombinasikan konteks pengalaman, interpretasi dan refleksi yang siap untuk diterapkan dalam keputusan dan kegiatan (Davenport, et al., 1998). Pengetahuan tacit memiliki tiga karakteristik utama yaitu, (1). Bersifat action oriented termasuk individu yang mengetahui cara melakukan sesuatu, hal ini berlawanan dengan "knowing that". (2). Memberikan kesempatan pada individu untuk mencapai tujuan personalnya. (3). Biasanya tidak memerlukan bantuan orang lain, bahkan biasanya hanya diketahui oleh individu sendiri dikarenakan biasanya tidak terucapkan.

Ketika organisasi mempunyai sumberdaya yang didistribusikan ke suatu ak- tivitas maka mereka mungkin tidak sadar dengan eksistensi/keberadaan dari sumberdaya yang dimiliki untuk menciptakan keunggulan bersaing. Oleh karena itu, organisasi harus melakukan aktivitas pencarian sumberdaya yang dapat digunakan untuk membangun, mempertahankan dan menghasilkan sumberdaya intelektual.

Menurut sudut pandang bisnis, pengetahuan dapat didefinisikan sebagai informasi relevan yang dapat diaplikasikan sebagai dasar dari pengalaman (Leonard dan Sensiper, 1998). Sehingga dapat disimpulkan bahwa pengetahuan merupakan suatu kemampuan yang dimiliki oleh individu atau kelompok yang dapat digunakan untuk mencari, menyimpan dan memproses informasi untuk kemudian diaktualisasikan menjadi pengalaman. Pengetahuan menunjukkan perilaku individu dan menjadi sumber dari keunggulan bersaing harus dapat ditransformasikan ke dalam pengetahuan organisasi (Grant, 1996; Nonaka dan Konno, 1998; Powell, 1998). Hal ini merupakan esensi dari manajemen pengetahuan dan dapat menyediakan tujuan yang ingin dicapai, organisasi harus menyediakan konteks pembagian identitas yang menunjukkan suatu proses (Kogut dan Zander, 1996; Szulanski, 2003).

\section{Desain Organisasi}

Kates dan Galbraith (2007) menyatakan bahwa struktur dan desain organisasi adalah suatu strategi yang diterjemahkan ke dalam lima bidang yang terkait. Desain organisasi dipengaruhi oleh kemampuan organisasi, individu yang ada pada organisasi, struktur organisasi yang digunakan, proses pengambilan keputusan serta sistem penghargaan. Kelima komponen yang 
mempengaruhi desain organisasi yang dirancang akan menentukan bentuk strategi yang akan diterapkan oleh organisasi. Ketika organisasi ingin menciptakan dan mempertahankan keunggulan bersaing, maka mereka dapat memodifikasi kelima komponen yang ada pada desain organisasi yang ada. Organisasi dapat melakukan inovasi melalui kemampuan untuk membedakan diri dengan pesaing, pengem- bangan ketrampilan, sikap dan perilaku yang ditunjukkan dalam mencapai tujuan, kebijakan atau aturan yang berlaku pada organisasi serta proses pengambilan keputusan yang digunakan.

Menurut Miller dan Droge (1986) meringkas perbedaan yang ada pada desain organisasi sebagaimana yang tertera pada tabel 1 berikut.

Tabel. 1 Perbedaan Desain Organisasi

\begin{tabular}{lll}
\hline Mechanistic design & High formalisation & Extensive use of written procedures \\
\hline & High degree of task specialitasion \\
\hline Low integration & Strict performance control \\
\hline & Little use of lialison process \\
\hline Hrganic design centralisation & Little use of lialison structures \\
\hline Low formalisation & Little use delegation of decision making authority \\
\hline & Little use of written procedures \\
\hline High integration & Low degree of task specialisation \\
\hline & Relaxed performance control \\
\hline Low centralisation & Extensive use of lialison process \\
\hline
\end{tabular}

Sumber : Miller dan Droge (1986)

\section{Desain orgasasi pada Pembelajaran Organisasi}

Desain organisasi merupakan kontinum antara desain mekanik dan desain organik. Berdasarkan perbedaan yang ada pada desain organisasi, maka dapat dikatakan bahwa desain organisasi pada organisasi yang melakukan pembelajaran lebih baik menggunakan pendekatan desain organik. Desain ini mempunyai karakteristik adanya formalitas pada organisasi, sistem sentralisasi rendah dan integrasi yang tinggi. Outcomes yang ada pada desain organik adalah ; (1) peningkatan inovasi dan kreatifitas, (2) peningkatan efisiensi dan (3) menekankan pada perubahan yang efektif dan sesuai diterapkan pada lingkungan yang tidak pasti. Sebaliknya, pendekatan desain mekanis yang mempunyai karateristik integrasi yang rendah dan formal serta sentralisasi yang tinggi, pendekatan ini dianggap kurang sesuai untuk diterapkan pada organisasi yang sedang melakukan 


\section{Fathor A.S \& Mohammad Arief / Pembelajaran Organisasi UKM....}

proses pembelajaran. Ketidaksesuaian penggunaan desain mekanis pada organisasi yang melakukan pembelajaran disebabkan karena outcomes yang ada pada desain ini adalah ; (1) desain mekanis menuntut adanya minimalisasi biaya, (2) maksimalisasi efisiensi dan (3) stabilitas efektifitas dan sesuai diterapkan pada lingkungan yang pasti.

Intensitas pengetahuan yang dikembangkan oleh organisasi akan meninggalkan struktur formal dan koordinasi dilakukan melalui penghargaan sosial dan sistem normatif internal. Beberapa model pembelajaran organisasi akan menghubungkan perubahan eksternal dengan kebutuhan organisasi untuk melakukan pembelajaran. Pendekatan dinamis pada perubahan sosial merupakan cara yang baik untuk merancang proses pembelajaran organisasi, dengan membiarkan pengembangan baru dan diversifikasi.

Sumber daya organisasi seperti, pengetahuan, kemampuan untuk melakukan pembelajaran, budaya, tim kerja dan sumberdaya manusia, kepentingan organisasi melakukan pembelajaran, struktur organisasi dan infrastruktur serta kepemimpinan merupakan elemen yang paling dapat memberikan kontribusi terhadap keunggulan kompetitif yang berkelanjutan (Hitt, et al, 2001a;. Barney, 2001a). Kemampuan organisasi muncul dari waktu ke waktu melalui proses pembelajaran organisasi (Levitt dan March, 1988; Szulanski, 2003). Sebagai konsekuensinya, pemeliharaan keunggulan kompetitif organisasi mungkin bergantung pada keputusan masa lalu dan cara karyawan didalam melakukan pembelajaran dari pengalaman masa lalu (Alvarez dan Busenitz, 2001). Dengan memanfaatkan pengetahuan yang ada pada organisasi, maka akan memperbesar dasar pengetahuan dan pengembangan budaya yang merupakan stimulus untuk pembelajaran organisasi.

\section{Model Penciptaan Keungulan Bersaing Berbasis Sumberdaya Manusia ; Pembelajaran Organisasi, Pengetahuan dan Desain Organisasi.}

Penciptaan keunggulan bersaing berbasis sumberdaya manusia dapat dihasilkan dari proses pembelajaran yang dilakukan oleh individu yang ada pada organisasi. Individu akan melakukan pembelajaran dengan mengakuisisi semua informasi yang diterima dan pada tahap selanjutnya informasi tersebut akan menjadi suatu pengalaman. Pengetahuan yang dimiliki oleh individu atau kelompok dapat diperoleh melalui pelatihan dan berbagai bentuk pengembangan yang dialami oleh individu. Pada tahap ini, faktor kognisi dari individu mempunyai peranan yang sangat besar untuk menciptakan pengalaman. Pengetahuan dan pengalaman yang dimiliki oleh individu akan dibagi ke kelompok kecil yang ada pada organisasi. Sebaliknya, kelompok yang ada pada organisasi juga akan membagi pengetahuan dan pengalaman kepada individu.

Pada tahap selanjutnya pengetahuan dan pengalaman dari kelompok akan dibagi ke lingkup yang lebih luas, yaitu organisasi. Pada tahap ini, organisasi akan mengintegrasikan pengetahuan yang dimiliki ke dalam kelompok kecil dan unit terkecil dari sumberdaya manusia yang ada pada organisasi, yaitu individu sehingga 


\section{Jurnal Ekonomi Modernisasi, 13 (2) 2017, 105-118}

akan terjadi transformasi pembelajaran individu menjadi pembelajaran organisasi melalui pengetahuan.

Ketika organisasi sudah melakukan pembelajaran maka pengetahuan yang mereka peroleh akan digunakan untuk mengembangkan organisasi. Salah satu bentuk pengembangan organisasi yang dapat dihasilkan melalui pembelajaran yang telah dilakukan misalnya menentukan desain organisasi. Dari penjelasan sebelumnya, desain organisasi dapat dibedakan menjadi desain organik dan desain mekanik. Penjelasan tentang perbedaan tersebut mengindikasikan bahwa untuk organisasi yang sedang berada pada tahap pembelajaran, maka desain organisasi yang dirancang sebaiknya diarahkan pada desain organik. Berikut kerangka konseptual pembelajaran organisasi, (Gambar 1)

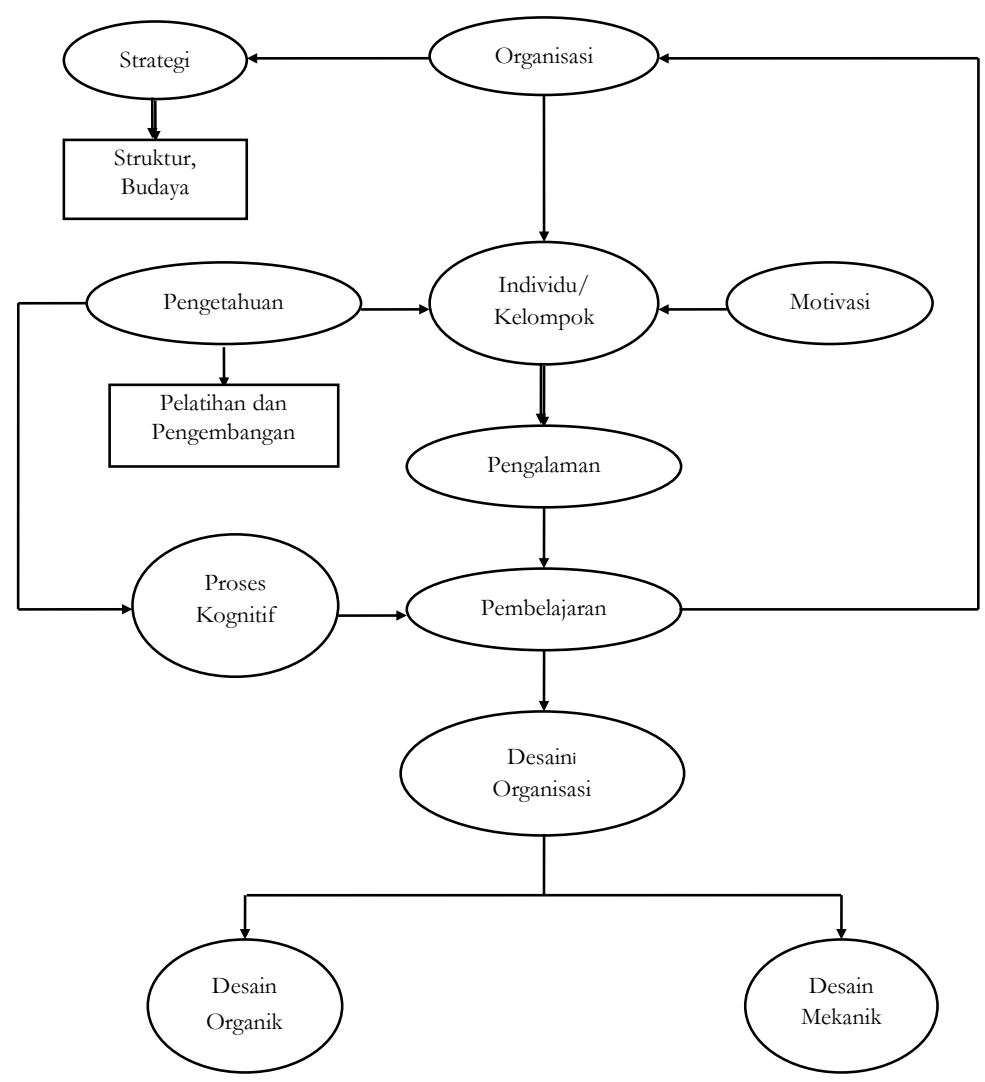

Gambar 1. Kerangka Konseptual

\section{Simpulan}

Terdapat beragam konsep, terminologi yang menggambarkan pernyataan dari teori tema tersebut. Keinginan akan teori yang diinginkan dan seragam yang diterima akademisi dapat dicapai dengan penelitian, menggabungkan deduksi teoritis pada penelitian yang dilakukan. Meskipun banyak yang harus dilakukan, dampak dari pembelajaran organisasi pada desain organisasi memberikan beberapa karakteristik penting. Pertama, desain organisasi untuk pembelajaran organisasi pada UKM 


\section{Fathor A.S \& Mohammad Arief / Pembelajaran Organisasi UKM....}

seharusnya mengikuti pendekatan desain organik. Kedua, integrasi dan kombinasi dari pengetahuan adalah cara yang baik untuk mendesain organisasi dalam pembelajaran organisasi UKM. Ketiga, kemampuan organisasi muncul seiring waktu melalui proses pembelajaran organisasi UKM. Keempat, penghargaan sosial dan sistem normatif UKM merupakan cara yang baik untuk mendesain organisasi untuk pembelajaran organisasi. Kelima, pendekatan dinamis pada perubahan sosial adalah cara yang baik untuk mendesain organisasi UKM untuk pembelajaran organisasi, membiarkan pengembangan baru dan diversifikasi. Keenam, mengetahui bahwa individu mampu untuk belajar dari pengalaman lalu dan bahwa mereka tidak sepenuhnya rasional dalam proses pengambilan keputusannya adalah cara yang baik untuk mendesain organisasi untuk pembelajaran organisasi UKM. Ketujuh, mempertimbangkan dimensi sosial dari pembelajaran adalah cara yang baik dalam cara yang baik untuk mendesain organisasi untuk pembelajaran organisasi, daripada mempertimbangkan bahwa belajar hanya individu dan tidak dipengaruhi oleh elemen sosial.

\section{Daftar Pustaka}

Alvarez, S. dan Busenitz, L., 2001, The entrepreneurship of resource-based theory, Journal of Management, Vol. 27, pp. 755-775.

Antal, A., Dierkes, M., Child, J. dan Nonaka, I., 2003, Handbook of Organizational Learning \& Knowledge. Oxford: Oxford University Press.
Baker, W. dan Sinkula, J., 1999, The Synergistic Effect of Market Orientation and Learning Orientation on Organizational Performance, Journal of the Academy of Marketing Science, Vol. 27, No. 4, pp. 411-427.

Barney, J.B., 1991, Firm Resources And Sustained Competitive Advantage, Journal of Management 17,99-120.

Barney JB. 2001a. Resource-Based Theories Of Competitive Advantage: A Ten- Year Retrospective On The Resource-Based View. Journal of Management, Vol. 27 No. 6, pp. 643650.

Bontis, N., Crossan, M. dan Hulland, J., 2002, Managing an organizational learning system by aligning stocks and flows, Journal of Management Studies, Vol. 39, No. 4, pp.437-469.

Collis, D., 1991, A resource-based analysis of global competition: the case of bearings industry, Strategic Management Journal, Vol. 12, pp. 49 $-68$.

Cook, S. dan Yanow, D., 1995, Culture and Organizational Learning, In Cohen and Sproull (Eds.) Organizational Learning, Thousand Oaks, CA: Sage Publications, pp. 430-459.

Cornwall, R.J. dan Perlman, B., 1990, Organizational Entrepreneurship, Irwin, Boston, MA.

Currado, Carla, 2006, Organizational Learning And Organizational Design, The Learning Organization, Vol. 13 No. 1, pp. 25-48.

Crossan, M., Lane, H. dan White, R., 1999, An organizational learning framework: from intuition to institution, Academy of Management Review, Vol. 24, No. 3, pp.522-537.

Crossan, M. dan Berdrow, I., 2003, Organizational learning and strategic renewal, Strategic Management Journal, Vol. 24, pp.1087-1105.

Crossan, M. dan Hulland, J., 2002, Leveraging knowledge through 
leadership of organizational learning, in C. Choo and N. Bontis (Eds). The Strategic Management of Intellectual Capital and Organizational Knowledge, New York: Oxford University Press, pp.711-723.

Daft, R.L., 2006, The new era of management. Thomson SouthWestern: Ohio.

Daft R. L., Weick K. E., 1987, Toward a Model of Organizations as Interpretation Systems, American Management Review, Vol. 9, pp. 284 $-295$.

Damanpour, F., 1992, Organizational size and innovation, Organizational Studies, Vol. 13 No. 3, pp. 375-402.

Davenport, T. H., De Long, D. W., dan Beers, M. C., 1998, Successful Knowledge Management. Sloan Management Review, 39(2), 43-57.

DeNisi, A., Hitt, M. dan Jackson, S., 2003, The Knowledge-Based Approach to Sustainable Competitive Advantage, In Jackson, Hitt and DeNisi (Eds.) Managing Knowledge for Sustained Competitive Advantage, San Francisco: Jossey-Bass, pp. 3-33.

Drucker, P., 1985, Entrepreneurship and Innovation: Practice and Principles, Harper Business, New York, NY.

Figueiredo, P., 2003, Learning, capability accumulation and firms differences: evidence from latecomer steel, Industrial and Corporate Change, Vol. 12 No. 3, pp. 607-643.

Garvin, David A., 1993, Building a Learning Organization, Harvard Business Review, Vol. 71 No. 4, pp. 78-91.

Ghili, Soheil, Serima Nazarian, Madjid Tavana, Sepehr Keyvanshokouhi, Mohammad Taghi Isaai, 2013, A Complex Systems Paradox of Organizational Learning and Knowledge Management, International Journal of KnowledgeBased Organizations, Vol. 3 No. 3, pp. $53-72$.
Grant, R., 1996, Towards a knowledgebased view of the firm, Strategic Management Journal, Vol. 17, pp.109 -122 .

Hitt, M., Bierman, L., Shimizu, K. dan Kockhar, R., 2001a, Direct and moderate effects of human capital on strategy and performance in professional service firms: a resourcebased perspective, Academy of Management Review, Vol. 44 No. 1, pp. 13-28.

Hurley, R.F. dan Hult, G.T.M., 1998, Innovation, market orientation, and organizational learning: an integration and empirical examination, The Journal of Marketing, Vol. 62, pp.42-54.

Huizing, A. dan Bouman, W., 2002, Knowledge and learning markets and organizations, in C. Choo and N. Bontis (Eds). The Strategic Management of Intellectual Capital and Organizational Knowledge, New York: Oxford University Press.

Hult, G. Thomas M. dan O. C. Ferrell. 1997a., A Global Learning Organization Structure and Market Information Processing, Journal of Business Research, Vol. 40 No. 2, pp. 155-166.

Hult, G. Tomas M., O. C. Ferrell dan Robert F. Hurley, 2002, Global Organizational Learning Effects On Cycle Time Performance, Journal of Business Research 55 377-387.

Kates, A. dan Galbraith, J.R., 2007, Designing Your Organization, San Francisco: Jossey-Bass.

King, A.W., Zeithaml, C.P., 2003, Measuring Organizational Knowledge : A Conceptual And Methodological Framework, Strategic Management Journal 24, 763-772.

Kogut, B., Zander, U., 1992, Knowledge Of The Firm, Combinative Capabilities, And The Replication Of 


\section{Fathor A.S \& Mohammad Arief / Pembelajaran Organisasi UKM....}

Technology, Organization Science 3 (3), 383-397.

Kogut, B., Zander, U., 1996, What Firms

Do : Coordination, Identity And Learning, Organization Science 7, 502-518.

Lei, D., Hitt, M. dan Bettis, R., 1996, Dynamic Core Competences through Meta Learning and Strategic Context, Journal of Management, Vol. 22 No. 4, pp. 549-569.

Leonard, Dorothy A. dan Sylvia Sensiper, 1998, The Role of Tacit Knowledge in Group Innovation, California Management Review, Vol. 40 No. 3, p p . $\quad 112-32, \quad$ D O I : $10.2307 / 41165946$.

Leonard-Barton, D., 1992, Core Capabilities And Core Rigidities : A Paradoxin Managing New Product Development, Strategic Management Journal 3, 111-125 (Summer Special Issue).

Levitt, B., dan March, J. G., 1988. Organizational learning. Annual Review of Sociology, Vol. 14, pp. 319-340.

Lukas, Bryan A., G. Tomas M. Hult, dan O. C. Ferrell. 1996. A Theoretical Perspective of the Antecedents and Consequences of Organizational Learning in Marketing Channels, Journal of Business Research, Vol. 36 No. 3, pp. 233-244.

March, James G., 1991, Exploration and Exploitation in Organizational Learning, Organization Science, Vol. 2, No. 1, Special Issue: Organizational Learning, pp. 71-87.
Miller, D., 1996, A Preliminary Typology of Organizational Learning: Synthesizing the Literature, Journal of Management, Vol. 22 No. 3, pp. 485-505.

Miller, D. dan Dröge, C., 1986, Psychological and traditional determinants of structure, Administrative Science Quarterly, Vol. 31 No. 4, pp. 539-560.

Nonaka, I. dan Konno, N., 1998, The Concept Of $\mathrm{Ba}$ : Building A Foundation For Knowledge Creation, California Management Review, Vol. 40 No. 3, pp.40-54.

Pawlowsky, P., 2003, The Treatment of Organizational Learning in Management Science, In Dierkes, Antal, Child and Nonaka (Eds.) Handbook of Organizational Learning \& Knowledge. Oxford: Oxford University Press, pp. 62-88.

Pfeffer, J., 1994, Competitive advantage through people, Boston: Harvard Business School Press.

Porter, M. E., 1985, Competitive Advantage : Creating and Sustaining Superior Performance, Free Press, NewYork, NY.

Porter, M.E. dan S. Stern, 1999, The New Challenge to America's Prosperity: Findings from the Innovation Index, Washington (DC): Council on Competitiveness.

Powell, W. W., 1998, Learning from collaboration: Knowledge and networks in the biotechnology and pharmaceutical industries, California Management Review, Vol. 40 No. 3, pp. 228-240. 
Peng Yu-Chuan, Zhen-Gang Zhang dan He Shen, 2017, The Effect of Organizational Learning and Knowledge Management Innovation on SMEs' Technological Capability, EURASIA Journal of Mathematics Science and Technology Education, pp. 5475-5487, DOI: 10.12973/ eurasia.2017.00842a.

Sinkula, J. M., 1994, Market Information Processing And Organizational Learning. J Mark 1994 ; 58 : 35-45 (January).

Sinkula, J. M, Baker W. E, Noordewier T., 1997, A Framework For MarketBased Organizational Learning : Linking Values, Knowledge, And Behavior., J Acad Mark Sci 1997 ; 25 : 305-18 (Fall).

Slater S. F dan Narver J. C. , 1994, Market Oriented Isn't Enough : Build A Learning Organization. Marketing Science Institute Report Number 94 -103. Cambridge, MA : Marketing Science Institute.

Slater S. F dan Narver J. C., 1995, Market Orientation And The Learning Organization. J Mark ; 59 : 63-74.

Spender, J.C., 1996, Making Knowledge The Basis Of A Dynamic Theory Of The Firm, Strategic Management Journal 17, 45-62 (Winter Special Issue).

Szulanski, G., 2003, Sticky Knowledge barriers to knowing in the firm, London: Sage Publicatios Ltd.

Teece, D., Pisano, G. dan Shuen, A., 1997, Dynamic capabilities and strategic management, Strategic Management Journal, Vol. 18 No. 7, pp. 509-534.
Tetrick, L. dan Da Silva, N., 2003, Assessing the Culture and Climate for Organizational Learning, In Jackson, Hitt and DeNisi (Eds.) Managing Knowledge for Sustained Competitive Advantage, San Francisco: Jossey-Bass.

Thornhill, Stewart, 2006, Knowledge, innovation and firm performance in high-and low-technology regimes, Journal of Business Venturing 21, 687-703.

Wei, Zelong, Yaqun Yi dan Hai Guo, 2013, Organizational L e a $\mathrm{r} n$ i $\mathrm{n} g$ Ambidexterity, Strategic Flexibility, and New Product Development, Journal of Product Innovation Management, Vol. 31 No. 4, DOI: 10.1111/jpim.12126.

Winter, S., 1987, Knowledge and competence as strategic assets, In D. Teece (Ed.) The Competitive Challenge: Strategies of Industrial Innovation and Renewal. Cambridge, MA: Ballinger, pp. 159-184. 